\title{
Frank McCourt's Teacher Man: A Novel Approach to Teacher Learning and Professional Development
}

\author{
Renate Schulz \\ University of Manitoba
}

\begin{abstract}
The purpose of this research was to investigate how stories can be a learning tool to help teachers make sense of and learn from their own stories of teaching. The participants in this study were teachers enrolled in a graduate level course. Frank McCourt's novel, Teacher Man acted as a stimulus, springboard and guide for class discussions and for teachers writing their own story of teaching. My mode of inquiry included collecting the teachers' written responses to class readings, noting their oral responses during class discussions, asking them to complete a short questionnaire, and following up with a taped focus group three months after the completion of the course. By reading, hearing and discussing the stories of others, teachers came to recognize the power of stories. Writing their own stories helped them to understand their own practice better.
\end{abstract}

Keywords: Stories, teacher learning, inquiry

Renate Schulz is a Senior Scholar in the Department of Curriculum, Teaching and Learning at the Faculty of Education, University of Manitoba.

Email: rschulz@ms.umanitoba.ca 


\section{Frank McCourt's Teacher Man: A Novel Approach to Teacher Learning and Professional Development}

The purpose of this research was to investigate, document, and understand how stories can be a learning tool to help teachers make sense of and learn from their own stories of teaching.

The importance of story in the study of teaching has been richly documented in the literature (Canzoneri \& Diakew, 2000; Carter, 1993; Coles, 1989; Connelly and Clandinin, 1990, 1999; Dominice, 2000; Goodson, 2006; Jalongo \& Isenberg, 1995). In their work, Connelly and Clandinin (1999) talk about teachers' professional landscapes and state that access to those landscapes that will unlock professional development is best gained through story. Stories give meaningful form to experiences we have lived through.

Telling stories is an activity that orders meaning, and in this way narrative discourse contributes to knowing. The equating of narrating and knowing also has support from philological analysis. Know and narrate have a common origin in the IndoEuropean gna (Schulz, 1997). To narrate and to know, therefore, are intimately related actions. Through storying we order our knowing, moving back to beginnings to discover where we now are, and what direction we might want to take in the future. Our lives are made of stories and storytelling is the process we use in our every day lives to make sense or to add sense to what we have experienced. Presumably a similar process can be employed as a learning tool to help us make sense of and learn from our stories of teaching.

Storytelling is something practitioners already do. By reframing it as a form of reflective practice, it can lead to a meaningful exploration of the beliefs and values that underpin the decisions that shape teaching practice. Stories allow us to explore our teaching lives. They allow us to try out alternative ways of being in the classroom, and new ways of shaping our actions in the future. In this way, teachers' stories are an inquiry process that leads to professional growth and learning. Oberg (2004) writes:

In my work with teachers, I have determined that beginning with vignettes or stories from teachers' daily practice is crucial to developing insights firmly anchored in teachers' everyday realities. The starting point is practice rather than imported theory because insights that originate in someone else's theory are often difficult to connect to one's own everyday actions ... and draw their attention to someone else's construction of reality (p. 231).

And Maxine Greene (2001) writes:

In my own teaching and in the communities of teacher education, I have tried to pay attention to lived lives: to life stories ... I have stressed the fruitfulness of novels, films, drama and even painting in effecting connections and in shedding light or going beyond (p. 84).

It is against this backdrop, within the context of a graduate level course, that I introduced Frank McCourt's (2005) Teacher Man to my class. Teacher Man is a memoir of McCourt's three decades as a teacher. In this paper I outline how this book played a role 
in the professional development of teachers by a) facilitating creative reflection, b) stimulating the teachers in the writing of their own stories, c) helping them to understand and learn about their own teaching, and d) effecting theory /practice connections for the teacher participants in this study.

\section{Context for this Study}

At the time of this study, I was teaching two sections of a graduate level course called the Study of Teaching. In the course outline that students received, I set out my beliefs and introduced the assignment of a teacher /career story, this way:

Teaching is a complex, dynamic and socially constructed activity, not always logical, frequently intuitive and invariably difficult to analyze and interpret. Teaching is about uncertainty. It is the place where design and circumstance collide. Although abundant research has been done to examine the nature of teaching, it is still far from being fully understood. But the uncertainty of teaching is also a source of excitement and opportunity. It can be the starting point for thinking about teaching as an inquiry process and viewing teaching as a learning profession.

In this course the focus of inquiry will be on our teaching selves. Because we teach out of who we are, our past acts as a prologue to our present teaching practices. Retrieving memories of our own learning experiences and reflecting on them can help us to make sense of what it is we do as educators, how we got here, and how our professional beliefs and practices have been shaped. Telling our personal stories of teaching and reflecting on them can lead to professional insight. Writing our teaching stories is another way to continue the dialogue about teaching and our professional life.

My experience of teaching this course over a period of five years was that many teachers in my classes were initially very sceptical about the value of stories or of relating their experiences of teaching, believing that stories had little worth beyond the lunch room. They were dismissive of the idea that teacher narratives might be a subject for teacher research or a legitimate tool for teacher learning. At best, the value of stories was limited, as in, if two people were teaching the same math unit, they could compare teaching stories, and then figure out how best to teach a concept. Dominice (2000) notes a similar resistance on the part of teachers to learning from subjective implications, as opposed to what teachers consider to be objective findings, and their lack of belief in their own ability to contribute to the production of knowledge.

Despite this scepticism and resistance, there was also evidence each year of how some teachers in the class did indeed find their professional voice through story, and how personal narratives led to professional insight. In one such example, a class member came to realize that her teaching practice was not nearly as student centered and collaborative as she claimed. In fact, she discovered that she was much more a transmission teacher than she realized, and wanted to change her practice. To do so, she began to research the tenets of constructivist learning and started her personal change process on a small scale, 
teaching a unit on mythology to her grade eight class differently, informed now by her new understandings about herself and her former teaching practice.

For this teacher, writing her own story played a role in her professional growth. It helped her to grapple with her own prior beliefs. The response of this teacher illustrates precisely, Bullough's (1997) contention that "through story telling personal theories become explicit, and in being made explicit they can be changed, where change is warranted, and a new or different story results; we behold differently" (p. 19).

I continued to make teachers' stories or educational autobiographies a part of the course requirements, and it is the mixture of the teachers' resistance and positive responses that prompted the study which I report on in this paper.

\section{The Study}

My guiding question was "What happens when I use a novel to help practising teachers reflect on and write about their teaching lives and practices?" The participants in this study were 22 teachers, enrolled in two different sections of a graduate level course. Their teaching experience ranged from two to about twenty years in the classroom. For some, this was their first graduate course, for others it was the last course in their program. My mode of inquiry included collecting the teachers' written responses to class readings, noting their oral responses during class discussions, asking them to complete a short questionnaire, and following up with a taped focus group three months after the completion of the course.

I began my research with a clarification of the teachers' initial understanding of and disposition toward the place of story in teaching. Data sources here were the teachers' written responses to class readings, such as Carter's (1993) article on story, and their oral responses during small group discussions. While some teachers embraced the notion and value of story, those who were sceptical about its place in teaching and teacher education, expressed concern about the reliability and trustworthiness of stories and storytellers, asking how do you know people are telling the truth, how do you know they're not exaggerating? How can stories that change be useful for teacher learning or research? If they can't be generalized, of what use are they? Questions such as these, raised in their small groups, or drawn from the teachers' written responses, became part of our ongoing whole class discussion of the role of story.

At the same time that we were talking about story in theoretical terms, the teachers engaged in reflective writing and visioning exercises that acted as precursors to story telling/story writing. Because of their apprehensions about writing their own stories, we began with short pieces guided by writing prompts, or brief vignettes drawn from their memories. Congruent with the findings of Gervais and Desgagne (2003), a number of teachers in my study felt that their stories could only be valuable if they were exceptional in some way. They did not believe that their stories had worth. They thought their experiences too ordinary. This apprehension reflects a lack of recognition of their own expertise as practitioners, and suggests a parallel to McCourt's (2005) comment in Teacher Man that "the people in my class... thought their opinions did not matter" (p.119). Ironically, the same teachers who claimed that their teacher education courses had not taught them much, did not trust their own knowledge in the public sphere, but clung to academic theory and research to tell them "truths" about teaching. 
At first, the teachers' short responses to writing prompts consisted primarily of detailed literal descriptions of actual events from daily practice. Teachers used to telling casual lunch-hour stories about their practice were not used to looking carefully at their own work using a narrative mode of analysis, i.e. examining metaphors, recognizing themes, considering alternative interpretations, giving a title to their story and then sharing the different titles (and the different implied interpretations) with colleagues. As they continued to share and think more deeply about their own written vignettes of teaching and learning, one teacher who had initially been hesitant to participate commented: "This process gave me the courage to articulate my story." Another teacher validated the activities in this way: "The process encouraged me to do what I was already inclined to do, and the openness of the group helped me to feel comfortable."

After some time spent reading and discussing the research literature on various topics related to the study of teaching, and the teachers' own short stories or anecdotes of teaching, we turned to Teacher Man. Everyone had already read the book, and we used an informal book club format to discuss it in class. Reading Teacher Man gave participants an opportunity to see teaching through the eyes of another teacher. The focus was not on them, but more comfortably, on McCourt's stories of his experiences. The discussions around his experiences opened the door for the teachers' own stories and prompted a wide range of teacher stories to come forth. There was no effort to convey a value-neutral stance toward the described events, and the moral themes that came out of one speaker's story-telling were often elaborated or reinforced by another speaker's story.

Over time, through the discussions, participants came to realize that a narrative does not just tell what happens; it does not merely mirror the action. But rather, any representation of an action is also an interpretation, one story among many that can be told. One of the consequences was to see that it was not necessarily a liability of storytelling that so many versions are possible. (What they originally identified as the untrustworthiness of stories). They also began to see how the small writing exercises they had been engaging in up to that point could form the basis for their larger teacher story.

When they began to write their own teacher or career story for the class assignment, they were again encouraged to share and exchange stories and emerging interpretations with classmates. This created opportunities for catching levels of meaning that they had only partially grasped while living through something, and they recorded their new learning and deeper understandings in the rewriting of their stories. They began to see that the stories they composed offered answers to the question of who is the self that teaches?

Their stories reflected what they valued, and they pointed to underlying theories of teaching and learning. Informed by Greene (2001) and Oberg (2004), established theories came second, and were used to deepen and extend teachers' understandings of themselves and of their own situations, as they moved dialectically between the particular and the general.

A short questionnaire, distributed at the end of the course, was completed anonymously by 16 teachers. A taped focus group was conducted three months after the completion of the course, and the responses to both were analyzed to create categories and seek patterns. Examples of the teachers' responses and their connection to Jalongo and Isenberg's (1995) markers of professional development follow. After close and repeated readings it became clear that the teachers' responses supported Jalongo and 
Isenberg's (1995) assertions about the ways in which teachers' stories contribute to professional development. All respondents who completed the questionnaire at the end of the course indicated that the process of writing and talking about their teacher story helped them to "scrutinize", reflect on, and understand their teaching practice better. They used words like important, meaningful, great, difficult, an enlightening experience to describe the assignment.

Question 1. Did the process of hearing other class members' stories of teaching help you in telling or writing your story of teaching? Only one respondent said "no". All others indicated that the process caused reflection, helped trigger memories of teaching and learning, and helped them to see that others were dealing with similar issues. This was reassuring and gave them the courage to tell their stories. One of the participants in the focus group elaborated this way:

It's very valuable that a teacher story would be required in a course. It's the only course where I didn't feel sheepish discussing this underground stuff. I felt that any story I was telling was a valid contribution to the substance and the content of the course. My practice was part of the course content. The process of people having dialogue about practice and the interface between theory and practice is important.

Four respondents commented that the range of stories they heard in class highlighted and validated the diversity in teaching, and the diversity of lenses through which teaching can be viewed. As teachers became more aware of the interpretive nature of their storytelling, they also became more aware of the assumptions they were making, and recognized that their stories were not mirror images of their lived experiences. One teacher who participated in the focus group expressed his understanding this way:

Teachers account for themselves by having key stories that they tell about themselves. We all see ourselves in certain ways ... possibly as a jolly amiable person, or someone who is not good at athletics, and then we're surprised when others don't see us as jolly and amiable, or when we do well in athletics ... because both cases run counter to the narrative we've adopted for ourselves.

Another focus group participant made a parallel connection, drawing on an experience she had when she tried to teach math in a different way: "Along a similar vein, kids have a narrative of how school should be, how certain subjects should be taught, and when things are done differently, they're confused."

Question 2. Write about the role that McCourt's book played for you in telling or writing your story of teaching. Two respondents said it did not play a big role in their teaching story, but it did play a large role in their research assignment, where they chose to write about Noddings' ethic of care in relation to Teacher Man. Other respondents said that McCourt's book triggered memories, pointed to common themes or contrasting ideas about practice, and provided examples of diverse styles, as well as clear ideas and methods for writing a teacher story. One teacher wrote, "Reading McCourt made me want to share my stories of teaching." Another commented: "I feel I'm now more ready to voice my concerns and innovations about teaching because I am more adept at 
communicating them. The best part of the teaching story was that the group now had a common way or foundation of discussing, critiquing or reflecting on teaching."

Question 3. Did the process of writing your teacher story help you to understand your teaching practice in a different way? All respondents agreed that the process made them reflect on, and helped them to understand their teaching. Five respondents said that they now had a much better understanding of themselves and "what they were doing and thinking," variously referencing the following: their framework of beliefs seemed more coherent, less haphazard, they felt they had a better understanding of the origins of their beliefs, a better understanding of their reasons for entering the profession, their teaching focus, why their understandings of education had changed, and why they chose to highlight certain things in their story. Four respondents said that although there were no surprises of self-discovery, the process let them formalize thoughts that were already present and see themselves more clearly. Three respondents indicated that writing their teacher story helped them to highlight particular areas of strength and areas that they needed to continue developing, and that they now had a much better sense of direction for the future. Two teachers, however, expressed their disappointment that the exercise of writing their teacher story did not resolve for them, quite as definitively as they had hoped, their questions about whether they should stay in the profession. Four others commented on the process this way:

It made me question whether I want to change my practices or whether I still believe in what/how I'm teaching.

It gave me a vocabulary for my vision of teaching and let me relate it to a particular paradigm, theory, way of teaching.

It was nice to be able to see how rich and full my teaching career has been.

It helped me accept myself, not be so hard on myself.

\section{Linking Teachers' Stories, Teacher Learning, and Professional Development}

Reading Teacher Man together as a class invited the telling of our own stories of teaching, and it gave us all a common reference point from which to talk about stories of teaching. McCourt's book, as Maxine Greene (2001) suggested, played a role in "effecting connections and in shedding light or going beyond". As well, for some, it provided ideas or a model for how to write their stories.

It was also an enjoyable read, which is after all the purpose of reading novels. One teacher commented:

[It was] extremely refreshing to read a novel. For the past several years all the reading I have done has been highly academic. I have since recommended it to many of my teacher friends. I feel it puts a face to the 'teacher' identity for nonteachers, and teachers can relate to many of his frustrations and successes. 
While some saw McCourt's stories as very "real" and felt that teachers could relate to many of his struggles and successes, others didn't find him to be a sympathetic character. One teacher wrote: "he seemed under prepared, and I worry that the public will get the wrong idea of what teaching is ... show up, tell stories, and that's it." These different opinions speak to the openness of good stories, and the many interpretations possible within any one text, whether that text is a novel or the text of a teacher's story of practice.

It is the presence of multiple interpretations that contributes to the appeal and interest value of a story that generates the kind of conversations that 'effect connections, shed light and go beyond.' One teacher wrote that Teacher Man "has been circulated like a bad cold through my school ... leading to conversation, laughter, knowing looks, and professionalization."

Professional growth and learning are important outcomes of the use of story. The literature generally distinguishes between the terms professionalization and professionalism. Goodson and Hargreaves (1996) define professionalization as the "social and political project or mission designed to enhance the interests of an occupational group", and describe professionalism as "something which defines and articulates the quality and character of people's actions within that group" (4). I believe it is the latter definition that the teachers have in mind, even though they use the term 'professionalization, and I will explore the self-reported evidence of professional growth and learning as these appeared in the teachers' responses to the questionnaire and in the focus group.

In response to the teacher who wrote in the questionnaire that Teacher Man had been circulated through the school like a bad cold, leading eventually to professionalization, one of the focus group participants noted that she had also circulated the book by giving it as a gift. After reading it, the recipient remarked that it permitted her to see how she evolved as a teacher, and that the book validated the learning she was providing through her own teaching strategy of story telling. Another focus group member confirmed that the book had also circulated in his school.

There are now nine teachers who have read this book in my school. It's led to professionalization in that there are areas about teaching that we feel sheepish about, where we close our door. Circulating this book has facilitated conversations around those areas where we can take off our masks and confess ignorance.

His comment was met with this response:

The book leads to conversation, but professionalization? I don't think it goes that far. By the end of the book I was very tired of McCourt's ongoing, repeated, nothing is changing actions ... accepting, doing nothing about it. There's no reflection on teaching. Maybe reading about the fact that McCourt's not particularly reflective and feels compelled to do what is expected, as opposed to what might actually be effective... alerts us to the need for reflection ... to think about our purpose in the classroom ... are we here for social reproduction? ... and therefore, well I guess, maybe it does contribute to professionalization. Teachers don't usually dialogue about theory and practice, and pedagogy ... and maybe by reading Teacher Man, where it's so raw and uncensored, and truthful ... it leads to that kind of talk. 
Jalongo and Isenberg (1995) identify five significant ways in which teachers' stories contribute to professional development: 1) Teachers' stories invite reflective practice; 2) Personal narratives help teachers to find their voice; 3) Teachers' stories chronicle growth and change; 4) Teachers' stories promote an ethic of caring; 5) Teachers' stories can enhance cross-cultural understandings. These markers of professionalism were very evident in the responses of the teachers who participated in this study.

Teachers' stories invite reflective practice. All the teachers who participated in this research acknowledged that writing their teacher story helped them to reflect on their teaching practice. The following three quotes from the focus group illustrate the range of reflections:

I was very surprised how much of my past and my pre-teaching past found its way into my teacher story. It's not what I set out to do. I thought I would focus more on philosophy. How strong is that influence from the past on my practice? I'll have to think about that.

I felt liberated by reading some of McCourt's more ridiculous teaching approaches. So I thought OK I can do some of the things I do with my students. But I also had to ask is he justified in what he's doing? Am I justified in what I'm doing? So it made me think about my practice.

It was good to be able to talk about and hear that other people had these issues. But at the same time does it cause discontent or disequilibrium? Does it inadvertently encourage teachers to leave the profession? But the other side of the coin is teachers who are so totally unaware of the political and social ramifications of schooling... and that's equally undesirable.

Personal narratives help teachers to find their voice. This was confirmed many times in different ways. Teachers said that hearing such a range of stories helped them to see teaching from different perspectives, and this was reassuring to them. Hearing the stories of others gave them the courage to tell their own stories and have their voices heard. As one teacher pointed out: "We're not often asked to articulate our personal goals and purposes, so we don't have a vocabulary at the ready." Telling, hearing, and reading personal narratives helped to develop that vocabulary. The isolation of teaching, noted so frequently in the literature, was also addressed with concern:

How little I have explored my experiences through story would be entirely correlated with how often I talk to my colleagues, and at what level. Certain colleagues you talk to about stuff like that ... and other colleagues you talk to only at a content level. I might reflect internally, but I seldom talk with others at a pedagogy level, or another level. 
Several teachers took steps to overcome the isolation in their schools by inviting colleagues to observe them as they taught, and by "being more open with co-workers about what [they] actually did in [their] classrooms." Their hope was to create a professional learning community.

Can we visualize a different way of being in school where teachers could say 'I'm trying this in my classroom. Are there other people who might be trying a similar thing?' Can we visualize a place where teachers would talk about the things they're trying, teachers would ask 'how's that going' ... you needn't necessarily be working on the same thing, but there would be a shared interest.

Teachers' stories chronicle growth and change. Both the responses to the questionnaire and the discussion in the focus group included references to making changes in practice at the classroom level, and beyond. One teacher commented

I am consciously focusing on my own teaching and the changes I can affect in my classroom. I'm also trying to effect change in my school through encouraging more dialogue and having teachers observe each other in the classroom, but I don't honestly hold out much hope there.

The focus group members also began to talk about their work with teacher candidates and how they thought that their conversations with teacher candidates might change after their experiences in this class. Participants said that they would want teacher candidates to "grapple with some of the questions of which things needed to change, whether just in their personal practice or within the larger setting of the school ... to look for ways of joining theory and practice".

Teachers' stories promote an ethic of caring. Because we had spent class time reading about and discussing Noddings' (1992) ethic of care, this particular category in Jalongo and Isenberg's (1995) framework seemed particularly apt. The ethic of caring became a research focus for some, and the practice of caring was also evident in the in-class dialogue. Three teachers in the group wrote research papers connecting Noddings' work to Teacher Man. Their research certainly promoted an understanding of the ethic of care, which Noddings' (1992) describes in relational terms, as "a connection or encounter between two human beings - a carer and a recipient of care" (15). Noddings (1992) uses the term "engrossment" to describe the open receptivity within conversation of the onecaring. Engrossment means the one caring gives all his or her attention to the one caredfor. It requires that for the moment at least, we set aside all thoughts of self as we make room to fully take in the thoughts, words, and feelings of the other. This question from one of the teachers illustrates this quality of thoughtful attention to others: "Are we focusing on what teaching does for us, rather than actually getting into the minds of the kids, and asking how are you perceiving this?"

The following account from one focus group member of his relationship to another teacher in the class, clearly illustrates the quality of engrossment within the context of caring:

It was a learning experience for me because $\mathrm{X}$ and I were such philosophical opposites and I had prejudged her. If we hadn't shared stories, it would have 
stayed that way, but I gained a lot of respect for her. We had a chance in this class to talk about the experiences that shaped our orientation to curriculum, the compromises we agree or don't agree to make on our personal beliefs, and our feelings about how the school system affects our individuality. Because these came out in our teacher stories, they came out in our discussions ... and so we were better able to understand different teaching perspectives ... resolve differences such as those that I had with $\mathrm{X}$. I have great respect for her now because we were able to have those conversations.

Teachers' stories can enhance cross-cultural understandings. There are many cross citations in teacher education studies between the US, Canada, Australia and England, but our knowledge of what's happening in the rest of the world is much more limited. Currently the industrialized English speaking world controls most of the publishing outlets in teacher education and educational research, and when a major factor in publishers' decision making about what to publish is the number of copies a book will sell, then the voices of educators in smaller, non-English speaking areas are often excluded because they can't get published.

We need to develop more interactive patterns of communication that go beyond English speaking countries and connect with the rest of the world, so that we can enlarge our understanding of teaching. One way we can do this is through story. In addition to sharing stories in class of our personal teaching experiences in Korea, Hungary, and several African countries, we also read published stories about teaching in other cultural settings. Stigler and Hiebert's (1999) The Teaching Gap was of particular interest to the mathematics teachers in the class. This book gave them a new understanding of mathematics education in Japan, and a critical lens through which to view mathematics education in North America. It too became a book that was circulated among colleagues. It stimulated discussion in the schools where it was circulated, and in some cases it acted as a guide for changes in classroom practice.

\section{Discussion}

Telling stories of teaching is not just mindless chatter for the lunch room. It is evident from the responses of the teachers in this study that stories - their own, and the stories of others - activated tacitly held beliefs and theories of teaching, affirmed and challenged their learning and beliefs, increased their knowledge, freed them from the isolation of their classroom, and gave them a voice, and the courage to voice their knowing. For the teachers, writing their stories was not simply a process of recording their thoughts and experiences. It was a process of thinking. They ordered their knowing through writing. Through writing they were able to rethink events, to understand experiences and perceive themselves in new ways. In this way, teachers' stories became a process of inquiry that led to learning, and became an impetus for change.

The new scholarship of teaching and teacher education recognizes the enormous challenges of schooling in the twenty-first century and emphasizes the importance of having teachers who understand the complexity of their role, teachers who are critically thoughtful inquirers and ongoing learners. Autobiographical understanding is an important part of inquiring into what it means to practice as a teacher. For the 
experienced teachers in this study, McCourt's novel acted as an effective stimulus to their autobiographical inquiries and professional learning. Teacher educators who wish to promote practical and theoretical knowledge building can use novels and stories as inquiry tools equally effectively at the preservice level.

The notion of inquiry as a guiding principle for preservice teacher education was put forward over a century ago by Dewey (1904/1965), who criticized teacher education programs for placing too much emphasis on training and mastery or delivery of technical skills. He argued that, although first-hand practical experience in the schools was critical for the preparation of new teachers, the experience might well be miseducative if new teachers improved in the mechanics of teaching but failed to go on growing. Therefore, he advocated for teacher education programs which prepared new teachers to become critically thoughtful ongoing students of education. Some decades ago, Stenhouse (Rudduck and Hopkins, 1985) argued in a similar vein for the preparation of teachers to become extended professionals through engaging in inquiry. Today, as we acknowledge an expanded conception of the teacher as a knower, thinker, knowledge generator, and change agent, an emphasis on inquiry is becoming more evident in teacher education programs in North America and internationally (Schulz, 2010). By writing and reflecting on our stories of teaching we gain a better understanding of why we teach the way we do, how our teaching is connected to both our disciplinary backgrounds and our personal identities, and how we might teach differently. In this way teacher stories are an effective inquiry tool for educators at all levels.

The instances of learning, professional growth and change recorded in this study, are all self-reported by the participants. One way of extending and enriching this study would be to follow the teachers into their classrooms, to observe, confirm, and support their change efforts. A critical area for research is further inquiry into what is the actual impact of story on teacher practice and student learning. The conceptual scholarship on story is extensive and rich, but the empirical research on its catalytic validity is not as robust.

Goodson (2006) contends that we are living in the "age of small narratives" and cautions against unproblematized accounts of teachers' work. In class we discussed the fact that narrative has the potential to make our personal theories explicit, but doesn't necessarily do so, and can even act as a reifying element. We discussed how we reframed our stories, and one focus group member said: "What intrigues me is how we adjust reality to what it should be, compromise on things, make claims for and justify what we do." Another added: "It's good if it's a cycle where we have a story that affects the way we interpret our experiences, and then in turn our new experiences, or reading new theorists affects the narrative we tell about ourselves, but for some people, they have an unshakable narrative or ideology... and no experience alters it." Our learning in the class and our understanding of story would have been enriched, if we had spent more time going beyond the personal and practical, to explore the social construction of subjectivity, the scripted nature of stories, and the impact of their historical and structural contexts.

Isaac Bashevis Singer (1976) in Naftali, the storyteller and his horse Sus, writes, "When a day passes it is no longer there. What remains of it? Nothing more than a story. If stories weren't told or books weren't written, man would live like the beasts, only for the day. Today, we live, but by tomorrow today will be a story. The whole world, all 
human life, is one long story" (pp. 10-11). Aptly, the final comment in our focus group discussion centered on story. One of the teachers concluded the evening this way: "I have to have a second teacher story ... a story beyond the students... a story about why I'm here ...something that I can say to myself when I'm done ... that there is something different now than there was before."

Note

An earlier version of this paper was presented at the American Educational Research Association Conference in Chicago, April 2007.

\section{References}

Bullough, R. V. (1997). Practicing theory and theorizing practice in teacher education. In Loughran, J. \& Russell, T. (Eds.). Teaching about teaching (13-32). London: Falmer.

Canzoneri, P. \& Diakiw, J. (2000). Personal history inquiry. In Cole, A. \& Knowles, G. (Eds). Researching teaching (27-46). Needham Heights, MA: Allyn \& Bacon.

Carter, K. (1993). The place of story in the study of teaching and teacher education. Educational Researcher, 22(1), 5-12.

Coles, R. (1989) The call of stories: teaching and the moral imagination. Boston: Houghton Mifflin.

Connelly, F.M. \& Clandinin, D.J. (1999). Shaping a professional identity. New York: Teachers College Press.

Connelly, F. M. \& Clandinin, D.J. (1990). Stories of experience and narrative inquiry. Educational Researcher, 19(5), 2-14.

Dewey, J. (1904/1965). The relation of theory to practice in education. Borrowman, M. (ed.) Teacher education in America: A documentary history. New York: Teachers College Press.

Dominice, P. (2000). Learning from our lives. San Francisco: Jossey-Bass.

Gervais, F. \& Desgagne, S. (2003). The reconstruction process of teachers' narratives. Policy and Practice in Education, 10(1), 45- 59.

Goodson, I. (2006). The rise of the life of narrative. Teacher Education Quarterly, Fall, 7-21.

Goodson, I. \& Hargreaves, A. (1996). Teachers' professional lives. London: Falmer. 
Greene, M. (2001). Reflections on teaching. In Virginia Richardson (Ed.), Handbook of research on teaching. $4^{\text {th }}$ ed. (pp.82-89), Washington: American Educational Research Association.

Jalongo, M.R. \& Isenberg, J.P. (1995). Teachers' stories: From personal narrative to professional insight. San Francisco: Jossey-Bass.

McCourt, F. (2005) Teacher man. New York: Scribner.

Noddings, N. (1992). The challenge to care in schools. New York: Teachers College Press.

Oberg, A. (2004). Supervision as a creative act. Journal of the Canadian Association for Curriculum Studies, 1 (Spring), 227-238.

Rudduck, J. and Hopkins, D. (eds.) (1985). Research as a basis for teaching. Readings from the work of Lawrence Stenhouse. London: Heinemann.

Schulz, R. (2010). Inquiry-oriented teacher education. Baker, E., McGaw, B., Peterson, P. (eds.) International Encyclopedia of Education ( $3^{\text {rd }}$ ed.). Oxford: Elsevier.

Schulz, R. (1997). Interpreting teacher practice: Two continuing stories. New York: Teachers College Press.

Singer, I. B. (1976). Naftali the storyteller and his horse, Sus. New York: Farrar, Strauss \& Giroux.

Stigler, J. W. \& Hiebert, J. (1999). The teaching gap. New York: The Free Press. 